\title{
Evaluation of attitudes and knowledge of Kocaeli University medical students on dissection, brain death and organ donation
}

\author{
Belgin Bamaç ${ }^{1}$, Mehmet Deniz Yener ${ }^{1}$, Tuncay Çolak ${ }^{1}$, Rabia Taşdemir ${ }^{1}$, Elif Aksu ${ }^{1}$, Dilşat Güzelordu ${ }^{1}$, \\ İsmail Sivri ${ }^{1}$, Abdullah Örs ${ }^{1}$, Serap Çolak ${ }^{2}$ \\ ${ }^{1}$ Department of Anatomy, Faculty of Medicine, Kocaeli University, Kocaeli, Turkey \\ ${ }^{2}$ Department of Sports Management, Faculty of Sport Sciences, Kocaeli University. Kocaeli, Turkey
}

\begin{abstract}
Considering organ donation, cadaver supply routes and procurement rates, it seems that resources are limited. It is discussed from a broad perspective that the evaluation of ethical approaches in terms of cadaver needs in anatomy education and research areas, and the use of bodies obtained through donation are more appropriate. Healthcare workers' knowledge and attitudes on organ donation and transplantation are the main factors for making a positive impact on the society and raising the donation rate. In this study, the questions directed to the students were designed to assess their views on cadaveric and organ donation, their awareness of the issue, and their attitudes in case the person or his/her relatives need organ donation. When the obtained data were evaluated, statistically significant changes were observed between medical students' attitudes before and after the anatomy laboratory education $(p<0.05)$. Although many of the students stated that their ideas did not change, this study shows that medical school students change their attitudes towards cadaver and organ donation issues after anatomy laboratory training.
\end{abstract}

Keywords: cadaver donation; medical students; organ donation

Anatomy 2018;12(1):45-48 @2018 Turkish Society of Anatomy and Clinical Anatomy (TSACA)

\section{Introduction}

Cadaver and organ donation issues have become very important in terms of medical education and treatment of chronic diseases. It is also seen that resources are limited when organ donation, cadaver supply routes and acquisition rates are considered. ${ }^{[1,2]}$ Throughout the history of anatomy, acquiring cadavers became a major problem and the ethical debate on cadaver supply routes dates back to ancient history. Among these ways of supply, the most ethically correct method is thought to be donation of the human body or part of it voluntarily. ${ }^{[3,4]}$

As is known, anatomy knowledge is very important for most medical students. Anatomy education is carried out for two years, theoretical and practical. This situation can also affect students' attitudes towards cadaver donation. This questionnaire study among medical students who will become doctors of the future aimed to evaluate the effect of anatomy laboratory education on the knowledge, attitudes and behaviors of the medical students towards organ and cadaver donation.

\section{Materials and Methods}

Our questionnaire evaluation study was carried out between 2015-2016 and 2016-2017 academic year on students of Kocaeli University Faculty of Medicine. The attitudes of the Term-I students which have not yet received anatomy laboratory training, on cadaver and organ donation were questioned again on the same students in TermII after the anatomy laboratory training. A total of 166 students ( 80 females and 86 males) participated in the study. The students were asked 12 questions answers of which were including "Yes", "No" and "Undecided" choices. Before the questionnaire was re-applied to the Term-II 
students, the question "Do you think that medical education has changed your mind about organ and / or cadaver donation?" was added at the end of the questionnaire (Figure 1). The questions directed to the students were designed to assess their views on cadaveric and organ donation, their awareness of the issue, and their attitudes in case the person or his/her relatives need organ donation. The data obtained from the study were transferred to the computer and statistically analyzed using the IBM SPSS Statistics for Windows (Version 20.0, Armonk, NY, USA). Dependent samples t-tests were applied on the responses of the participants to the questionnaires after the descriptive statistics (mean value, standard deviation) were made. The answers given by each group for every question were analyzed by Pearson chi-square test according to pretest / posttest variables. The statistical significance was set at $\mathrm{p}<0.05$

\section{Results}

When gender, age and demographic characteristics are examined from the 166 students who participated in the

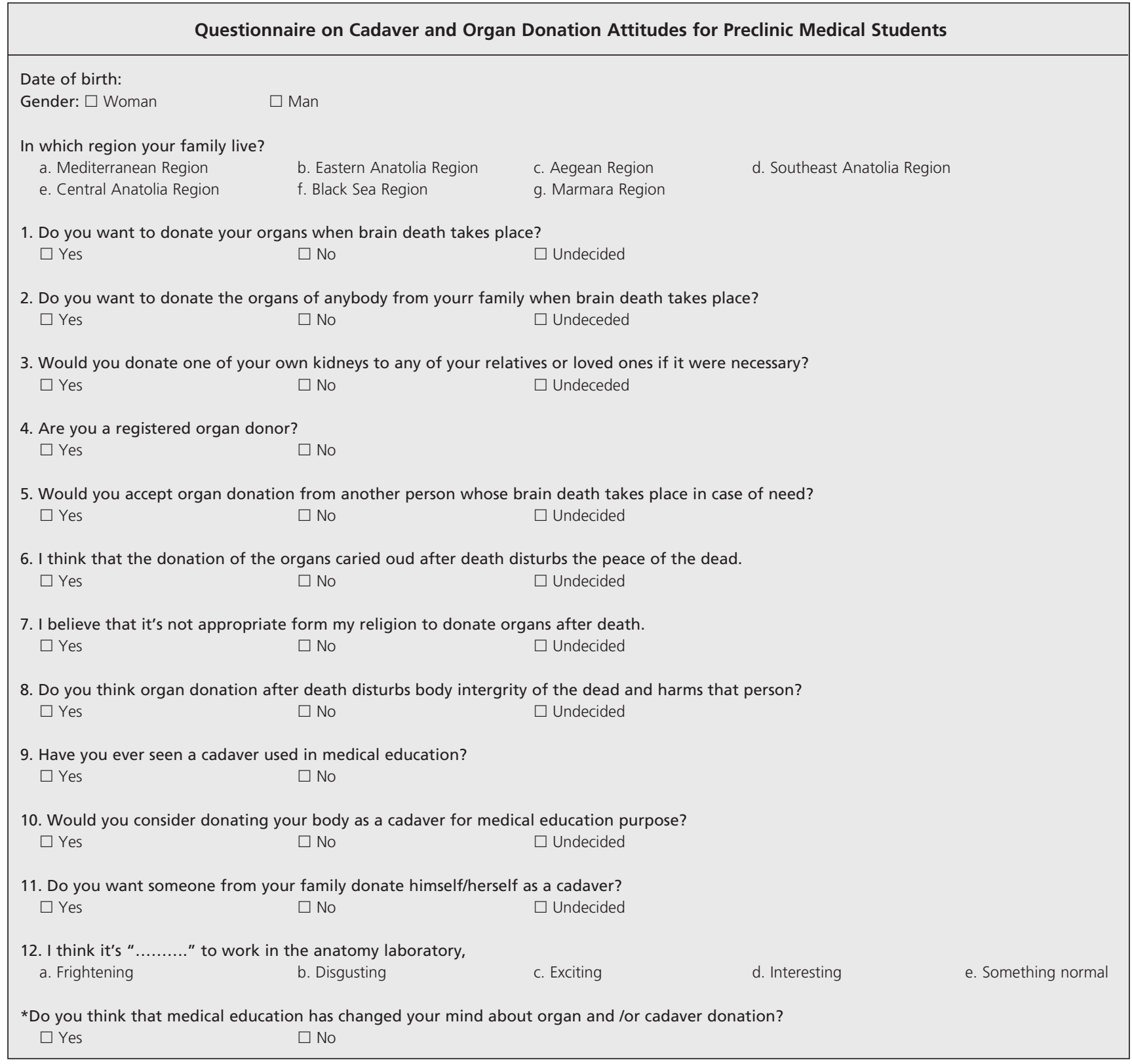

Figure 1. Questionnaire on cadaver and organ donation attitudes for preclinic medical students. *Extra question in the second questionnaire. 
Table 1

Percentages of answers that differ significantly from year to year for organ and cadaver donations $(p<0.05)$.

\begin{tabular}{|c|c|c|c|c|c|c|}
\hline \multirow[b]{2}{*}{ Questions } & \multicolumn{3}{|c|}{ 2015-2016 academic year } & \multicolumn{3}{|c|}{ 2016-2017 academic year } \\
\hline & Yes & No & Undecided & Yes & No & Undecided \\
\hline $\begin{array}{l}\text { 1. Do you want to donate your organs when } \\
\text { brain death takes place? }\end{array}$ & $38.6 \%(64)$ & $21.1 \%(35)$ & $40.4 \%(67)$ & $54.8 \%(91)$ & $18.1 \%(30)$ & $27.1 \%(45)$ \\
\hline $\begin{array}{l}\text { 2. Do you want to donate the organs of anybody from } \\
\text { your family when brain death takes place? }\end{array}$ & $31.9 \%(53)$ & $24.7 \%(41)$ & $43.4 \%(72)$ & $44 \%(73)$ & $27.7 \%(46)$ & $28.3 \%(47)$ \\
\hline $\begin{array}{l}\text { 3. Would you accept organ donation from another } \\
\text { person whose brain death takes place in case of need? }\end{array}$ & $72.9 \%(121)$ & $4.8 \%(8)$ & $22.3 \%(37)$ & $84.9 \%(141)$ & $3 \%(5)$ & $12 \%(20)$ \\
\hline $\begin{array}{l}\text { 4. Do you think organ donation after death disturbs } \\
\text { body integrity of the dead and harms that person? }\end{array}$ & $7.8 \%(13)$ & $70.5 \%(117)$ & $13.3 \%(22)$ & $10.2 \%(17)$ & $80.1 \%(133)$ & $9.6 \%(16)$ \\
\hline $\begin{array}{l}\text { 5. Would you consider donating your body as a } \\
\text { cadaver for medical education purpose? }\end{array}$ & $8.4 \%(14)$ & $59 \%(98)$ & $24.1 \%(40)$ & $9 \%(15)$ & $79.5 \%(132)$ & $11.4 \%(19)$ \\
\hline $\begin{array}{l}\text { 6. Do you want someone from your family donate } \\
\text { himself/herself as a cadaver? }\end{array}$ & $7.8 \%(13)$ & $65.1 \%(108)$ & $19.3 \%(32)$ & $5.4 \%(9)$ & $77.7 \%(129)$ & $16.9 \%(28)$ \\
\hline
\end{tabular}

study, $48.2 \%(\mathrm{n}=80)$ were males and $51.8 \%(\mathrm{n}=86)$ were females. The average age of the students in the academic year of 2015-2016 was 20.6. The geographical region in which the students' families resided was mostly \%60.8 $(n=101)$ the Marmara region. When the distributions of the answers according to years were taken into account, a total of 6 questions were observed with statistically significant difference $(\mathrm{p}<0.05)$ (Table 1).

When the obtained data were evaluated, it was observed that the anatomy laboratory education caused changes in the attitudes of medical students on cadaver and organ donation. When students were asked as "Do you want to donate your organs when brain death takes place?", 38.6\% (n=64) of them replied as "Yes". This ratio increased to $54.8 \%(n=91)$ in the following year $(\mathrm{p}<0.05)$.

Likewise, $31.9 \%(n=53)$ of the students answered yes to "Do you want to donate the organs of any one of your family members when the brain death takes place?" then this ratio increased to $44.0 \%(\mathrm{n}=73)(\mathrm{p}<0.05)$. Similar differences were also found in the increase in acceptance of organ donation $(\mathrm{p}<0.05)$.
In another question directed to the students, "How was the feeling of working with the cadaver in the anatomy laboratory" the answer choices were frightening, nauseating, exciting, interesting or normal. Statistically significant differences were determined when the answers given by the students in Term-I and Term-II were evaluated separately $(\mathrm{p}<0.05)$. In 2015-2016 education year, while $34.3 \%(n=57)$ of the students in Term-I described working in the anatomy laboratory as "normal", this ratio increased to $63.9 \%(n=106)$ among the same students in the following year (Table 2).

"Do you think that medical education has changed your mind about the organs and / or cadaveric donation?" When this question is directed to the Term-II students in anatomy laboratory training; 45.1\% (n=75) answered "Yes" and 54.9\% (n=91) answered "No" (Table 3).

\section{Discussion}

Healthcare professionals' knowledge and attitude to organ donation and transplantation are importantl factors to promote a positive influence and rise the donation rate. In parallel with the development of medical sciences, cadaver needs are increasing in the fields of anatomy and medical

Table 2

Distribution of the views of students participating in the research about the anatomy laboratory studies by years.

\begin{tabular}{lccccc}
\hline & \multicolumn{4}{c}{ I think it's "......" to work in the anatomy laboratory } \\
\cline { 2 - 6 } & Frightening & Disgusting & Exciting & Interesting & Something normal \\
\hline Term-I (2015-2016) & $0.6 \%(1)$ & $1.8 \%(3)$ & $24.7 \%(41)$ & $30.7 \%(51)$ & $34.3 \%(57)$ \\
Term-II (2016-2017) & $0 \%(0)$ & $3 \%(5)$ & $10.2 \%(17)$ & $22.3 \%(37)$ & $63.9 \%(106)$ \\
\hline
\end{tabular}


Table 3

Response for 'Do you think that medical education has changed your mind about organ and / or cadaver donation?'

Do you think that medical education has changed your mind about organ and / or cadaver donation?

\begin{tabular}{lcc}
\hline 2016-2017 academic year & Yes & No \\
\hline Term-II & $45.1 \%(n=75)$ & $54.9 \%(n=91)$ \\
\hline
\end{tabular}

research. In the history of medicine, there are various ways to supply cadavers. ${ }^{[5,6]}$ The view that the use of the cadavers obtained by donation being more appropriate is discussed from a broad perspective in terms of ethics. ${ }^{[7,8]}$ Statistically significant changes were observed between medical students' attitudes before and after anatomy laboratory education $(\mathrm{p}<0.05)$.

When the results obtained were evaluated, it was observed that, in case of brain death, students did not have a high enough positive attitude for them or their families to donate organs and bodies. However, it was also found that the rate of donation acceptance is higher when the same situation is questioned according to the needs of themselves or their families.

Intercalarily, a question was added to the questionnaire study after the anatomy laboratory training "Do you think that medical education changes your opinion on organ and / or cadaver donation?" at the same time. $54.9 \%(\mathrm{n}=91)$ of the answers given to this question constituted "No" (Table 3). However, when the answers given by the same medical students in Term-I and Term-II were evaluated, there were significant differences according to years $(\mathrm{p}<0.05)$, Table 1 .

Although majority of students declared that there was no change in their attitudes, the results showed that their attitudes towards cadaveric and organ donation changed after the anatomy laboratory study.

\section{Conclusion}

When the obtained data were evaluated, anatomy laboratory studies could be seen as a reason for the change in the attitudes of medical students towards cadaver and organ donation. When the respondents' attitudes towards donation of organs and cadavers were evaluated, an increase in the positive direction for the donation of the students' organs and a decrease in the cadaver donation orientations of the persons was observed. It is known that the cadaver needs are increasing day by day in terms of cadaver use periods and the importance of anatomy laboratory education.

In this context, healthcare professionals have the greatest responsibility in terms of creating social awareness on organ and cadaver donation issues. Given the responsibilities and duties of health workers in this regard, the promotion of this level is critical to increase the quality of community health and health education.

\section{References}

1. Wight C, Cohen B, Roels L, Miranda B. Donor action: a quality assurance program for intensive care units that increases organ donation. J Intensive Care Med 2000;15:2-9.

2. Dinsmore CE, Daugherty S, Zeitz HJ. Student responses to the gross anatomy laboratory in a medical curriculum. Clin Anat 2001;14: 231-6.

3. Bogh L, Madsen M. Attitudes, knowledge, and proficiency in relation to organ donation: a questionnaire-based analysis in donor hospitals in northern Denmark. Transplant Proc 2005;37:3256-7.

4. Dalal AR. Philosophy of organ donation: review of ethical facets. World J Transplant 2015;24:44-51.

5. Kleinman I, Lowy FH. Cadaveric organ donation: ethical considerations for a new approach. CMAJ 1989;15:107-10.

6. Mekahli D, Liutkus A, Fargue S, Ranchin B, Cochat P. Survey of firstyear medical students to assess their knowledge and attitudes toward organ transplantation and donation. Transplant Proc 2009;41:634-8.

7. Caplan A. bioethics of organ transplantation. Cold Spring Harb Perspect Med 2014;4:3.

8. Emson HE. The ethics of human cadaver organ transplantation: a biologist's viewpoint. J Med Ethics 1987;13:124-6.

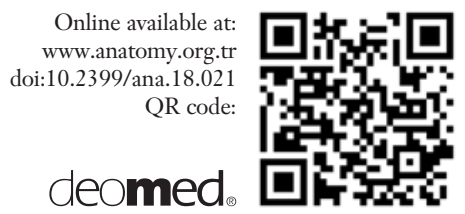

Correspondence to: Mehmet Deniz Yener, MSc Department of Anatomy, Faculty of Medicine,

Kocaeli University, Kocaeli, Turkey

Phone: +90 5448396647

e-mail: m.denizyener@hotmail.com

Conflict of interest statement: No conflicts declared.

This is an open access article distributed under the terms of the Creative Commons Attribution-NonCommercial-NoDerivs 3.0 Unported (CC BY-NCND3.0) Licence (http://creativecommons.org/licenses/by-nc-nd/3.0/) which permits unrestricted noncommercial use, distribution, and reproduction in any medium, provided the original work is properly cited. Please cite this article as: Bamaç B, Yener MD, Çolak T, Taşdemir R, Aksu E, Güzelordu D, Sivri İ, Örs A, Çolak S. Evaluation of attitudes and knowledge of Kocaeli University medical students on dissection, brain death and organ donation. Anatomy 2018;12(1):45-48. 